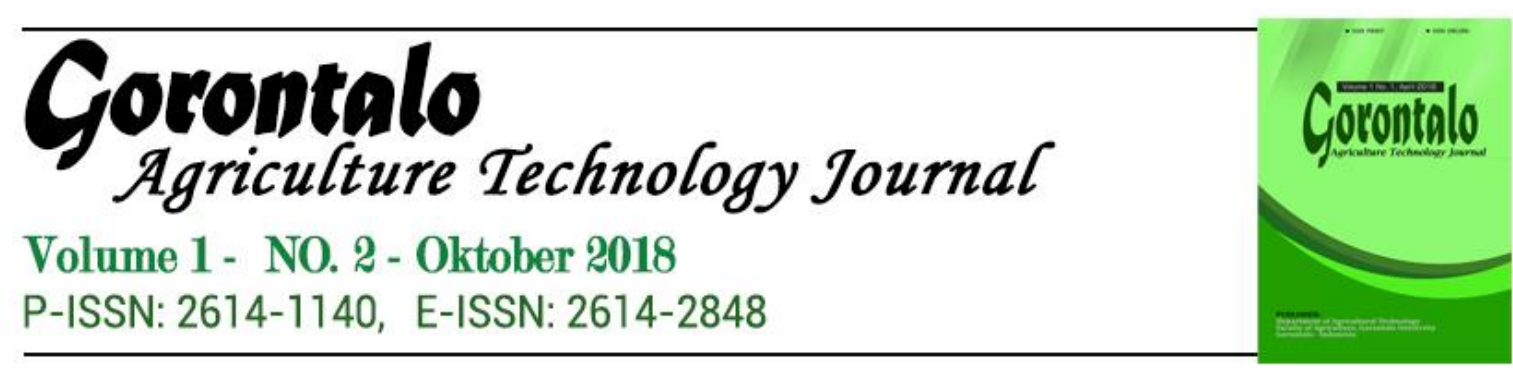

\title{
Pengaruh Konsentrasi Gula Terhadap Pembuatan Selai Kelapa Muda (Cocos nucifera L)
}

\section{Influnce Of Sugar Concentration on Making Young Coconut Jam (Cocos nucifera $L$ )}

\author{
Muh Arsyad \\ Teknologi Hasil Pertanian, Universitas Ichsan Gorontalo \\ Maner_b1@yahoo.com
}

\begin{abstract}
Abstrak
Selai merupakan produk makanan semi basah yang berbentuk setengah padat dan dibuat dari campuran gula, buah, dan pektin. Tujuan penelitian untuk mengetahui pengaruh konsentrasi gula yang tepat pada pembuatan selai kelapa muda dan tingkat penerimaan panelis terhadap selai kelapa muda dengan penambahan konsentrasi gula. Percobaan meliputi 4 perlakuan dan 3 ulangan. Perlakuan yang dimaksud adalah penambahan gula yaitu 300 g, 330 g, 360 g, 390 g. Parameter yang diamati adalah kadar air, kadar protein, kadar gula, dan uji organoleptik terhadap rasa, aroma, tekstur, dan warna selai kelapa muda. Penelitian ini menggunakan Rancangan Acak Lengkap (RAL). Hasil penelitian ini menunjukkan bahwa penambahan gula memberikan pengaruh sangat nyata terhadap kadar air, kadar protein, dan kadar gula selai kelapa muda. Penambahan gula 300 g menghasilkan selai kelapa muda dengan rasa manis yang cukup. Rasa khas dari buah kelapa muda masih terasa dan aroma tidak hilang serta tekstur yang lembut. Sedangkan warna selai kelapa muda panelis lebih menyukai penambahan gula $390 \mathrm{~g}$ dikarenakan warna yang kecoklatan sehingga menarik perhatian panelis. Untuk segi rasa, tekstur, dan aroma panelis lebih menyukai selai dengan penambahan gula $300 \mathrm{~g}$, sedangkan dari segi warna panelis lebih menyukai selai dengan penambahan gula $390 \mathrm{~g}$.
\end{abstract}

Katakunci : gula; kelapa muda; selai. 


\begin{abstract}
Jam is food products a semisolid wet spring and is made from a mixture of sugar, fruit, and pectin. The purpose of the study was to determine the effect of the right sugar concentration on the manufacture of young coconut jam and the level of acceptance of panelists on young coconut jam with the addition of sugar concentration. The experiment included 4 treatments and 3 replications. The treatment in question is the addition of sugar which is $300 \mathrm{~g}, 330 \mathrm{~g}, 360 \mathrm{~g}, 390 \mathrm{~g}$. The parameters observed were water content, protein content, sugar content, and organoleptic test for the taste, aroma, texture, and color of young coconut jam. This study uses a Completely Randomized Design (CRD). The results of this study indicate that the addition of sugar has a very significant effect on water content, protein content, and sugar content of young coconut jam. The addition of $300 \mathrm{~g}$ sugar produces young coconut jam with sufficient sweetness. The distinctive taste of young coconuts still feels and the aroma is not lost and the texture is soft. While the panelists' young coconut jam color preferred $390 \mathrm{~g}$ of sugar due to the brownish color that attracted the attention of the panelists. In terms of taste, texture and aroma panelists prefer jam with $300 \mathrm{~g}$ sugar addition, while in terms of color panelists prefer jam with sugar addition $390 \mathrm{~g}$.
\end{abstract}

Key words : jam; sugar; young coconut. 


\section{PENDAHULUAN}

Kelapa (nyiur) atau Cocos nucifera L, adalah tumbuhan palma pantai yang pohonnya tinggi, tanaman yang berusia cukup tua, yang banyak tersebar di seluruh daerah tropika. Pada permulaan tarikh masehi sudah dikenal dan dimanfaatkan orang dalam kehidupan sehari-hari. selanjutnya telah diusahakan sebagai barang dagangan ke berbagai tempat, baik keluar negeri seperti india, srilangka, dan ataupun di kepulauan Nusantara (Indonesia) di Asia dan sekitar lautan pasifik. Kelapa memang sudah merupakan tanaman penting yang di kenal masyarakat dan diduga kelapa mulai menyebar di Nusantara (Soekardi, 2014).

Kabupaten Pohuwato merupakan salah satu kabupaten yang mempunyai potensi sumber daya alam yang melimpah salah satu diantaranya adalah komoditas kelapa. Hasil produksi kelapa dari tahun ke tahun mengalami fluktuasi. Produk kelapa pada tahun 2013 yaitu sebanyak 22.910 ton, kemudian pada tahun 2014 mengalami penurunan menjadi 22.019 ton, tetapi kembali pada tahun 2015 produksi kelapa mengalami peningkatan sebanyak 22.929 ton (Dinas Pertanian dan Ketahanan Pangan Kabupaten Pohuwato, 2016).

Buah kelapa merupakan salah satu komoditas unggulan karena mudah di dapatkan dan dapat langsung di konsumsi. Buah kelapa juga dimanfaatkan untuk membuat santan, tepung santan, santan bubuk, minyak, kopra, nata de coco, kue tart, es kelapa muda. Pemanfaatan buah kelapa di Gorontalo hanya sebatas itu, Padahal potensi buah kelapa muda sangat besar. Namun masyarakat belum mengembangkannya menjadi sebuah produk yang bisa di jadikan komersial salah satunya adalah selai kelapa muda.

Selai merupakan produk makanan dengan konsisten gel atau semi padat yang di buat dari bubur buah. Konsistensi gel atau semi padat pada selai di peroleh dari senyawa pektin yang berasal dari buah atau pektin yang ditambahkan dari luar, gula sukrosa dan asam. Interaksi ini terjadi pada suhu tinggi dan bersifat menetap setelah suhu di turunkan. Kekerasan gel tergantung pada konsentrasi gula, pektin dan asam pada bubur (Trisnowati 2012). Selai kelapa muda termasuk pangan semi padat atau konsisten gel selai yang di peroleh dari pektin gula dan asam pada bubur kelapa muda.

Selai didefinisikan sebagai suatu bahan pangan semi padat yang dapat di oleskan dan di buat dari sedikitnya 45 bagian berat zat penyusun sari buah dengan 55 bagian berat gula. Campuran ini di kentalkan sampai mencapai kadar zat padat terlarut minimal 65 persen. Bahan-bahan yang dapat ditambahkan adalah zat warna, cita rasa, pektin, dan asam untuk melengkapi kekurangan dari buah itu sendiri (Arindya et al, 2016).

Selai kelapa muda sangat cocok di jadikan suatu produk di provinsi Gorontalo khususnya di Kab. Pohuwato. Karena bahan baku untuk pembuatan selai kelapa muda tersedia dalam jumlah yang sangat banyak yaitu kelapa muda dan gula dengan bahan tambahan pektin.

Konsentrasi gula yang cukup tinggi (70\%) sudah dapat menghambat pertumbuhan mikroba, akan tetapi pada umumnya gula di pergunakan dengan salah satu teknik pengawetan lainnya, misalnya dikombinasikan dengan keasamaan yang rendah, pasteurisasi, penyimpanan pada suhu rendah, dan lainlain (Ishak, 2012) 
Menurut Ishak (2012) sifat daya tahan dari selai di tentukan oleh gula sebagai bahan pengawet, kandungan gula yang tinggi, biasanya $65-75 \%$ bahan terlarut, keasaman tinggi, pH sekitar 3,1-3,5, suhu tinggi sewaktu pemanasan atau pemasakan $\left(105-106^{\circ} \mathrm{C}\right)$, kecuali pada evaporasi dan pengendapan pada suhu rendah, dan tekanan gas oksigen yang rendah selama penyimpanan, misalnya pada pengisian panas ke dalam wadah yang kedap udara

Tujuan penelitian ini adalah untuk mengetahui pengaruh konsentrasi larutan gula terhadap kadar air, kadar protein, dan kadar gula terhadap selai kelapa dan mengetahui tingkat penerimaan panelis terhadap selai kelapa dengan penambahan gula yang berbeda.

\section{METODOLOGI}

Penelitian ini di laksanakan di laboratorium Teknologi Hasil pertanian, Universitas Ichsan Gorontalo dan Balai Besar Industri Hasil Perkebunan Makassar. Alat yang di gunakan dalam penelitian ini yaitu baskom, panci, timbangan, blender, kompor gas, spatula, sendok, parang, wadah, kemasan, oven, cawan, desikator, kjedahl dan refraktometer.Bahan-Bahan yang di gunakan dalam penelitian ini adalah buah kelapa (daging dan air), gula pasir, pektin, kertas label, aquadest, $\mathrm{H}_{2} \mathrm{SO}_{4} 0,02 \mathrm{~N}$, dan $\mathrm{HBO}_{3}$.

Penelitian ini menggunakan Rancangan Acak Lengkap (RAL) faktor tunggal dan sebagai perlakuan yaitu Penambahan gula dengan berbeda konsentrasi. Adapun perlakuan yang digunakan yaitu A1 : 300 g gula, A2 : 330 g gula, A3 : 360 g gula, dan A4 : 390 g gula. Pembuatan selai kelapa muda dilakukan dengan cara daging kelapa muda di timbang sebanyak $300 \mathrm{~g}$ dan ditambahkan air kelapa $150 \mathrm{ml}$ kemudian dihaluskan hingga membentuk bubur. Gula dilarutkan sesuai perlakuan didalam air mineral $300 \mathrm{ml}$. Setelah gula larut ditambahkan bubur kelapa muda dan ditambahkan pektin $1 \mathrm{~g}$. Dimasak di dalam panci sambil diaduk secara perlahan dan menggunakan api yang kecil. Setelah kalis, selai yang masih panas di simpan dalam wadah untuk di dinginkan. Setelah dingin masukkan ke dalam kemasan.

Selai kelapa muda yang dihasilkan dianalisis secara kimia yaitu kadar air, kadar protein, kadar gula dan uji organoleptik. Pengukuran kadar air dilakukan dengan cara pengeringan didalam oven (Sudarmadji et al, 1997). Kadar air ditentukan dengan cara bahan ditimbang sebanyak $\pm 3 \mathrm{~g}$ dimasukkan dalam wadah yang telah diketahui beratnya, kemudian masukkan kedalam wadah yang telah diketahui beratnya, kemudian masukkan kedalam oven yang bersuhu $105^{\circ} \mathrm{C}$ selama 4 jam. Kemudian sampel didinginkan dalam eksikator selama 10 menit dan ditimbang. Panaskan lagi dalam oven selama 1 jam, dinginkan dalam eksikator dan ditimbang. Perlakuan ini diulangi sampai tercapai berat konstan (selisih penimbangan berturut - turut tidak lebih dari 0,02 gam). Perhitungan Kadar air bahan dilakukan sebagai berikut :

$$
\% \text { Kadar Air }=\frac{\text { Berat Awal }- \text { Berat Akhir }}{\text { Berat Awal }} \times 100 \%
$$

Pengukuran kadar protein dilakukan dengan cara bahan ditimbang kirakira 0,1 g dan dimasukan ke dalam labu kjeldhal. Tambahkan 7,5g KSO, 0,35g $\mathrm{HgO}$ dan $15 \mathrm{ml} \mathrm{H} 2 \mathrm{SO} 4$ pekat. Semua bahan dalam labu kjeldhal dipanaskan sampai mendidih dan menjadi jernih \pm 3 jam, lalu didinginkan ke dalam labu 
kjeldhal ditambahkan aquades sehingga volume menjadi $100 \mathrm{ml}$ kemudian ditambahkan perlahan-lahan larutan $\mathrm{NaOH} 50 \%$ sebanyak $50 \mathrm{ml}$ dan dipanaskan pada alat destilasi sampai mendidih. Destilat yang diperoleh campuran metil red dan bomokresol geen sampai berwarna hijau hingga merah. Titrasi destilat yang diperoleh dengan $\mathrm{HCl}$ 0,1 N hingga warna menjadi merah (Sudarmadji et al., 1997)

$$
\begin{aligned}
& \% \mathrm{~N}=\frac{(\mathrm{ml} \text { HCL Sampel }- \text { HCL blanko } \times \mathrm{N} \mathrm{HCl} \times 14,008)}{\text { mg Sampel }} \times 100 \% \\
& \% \text { Protein : \% N Total } \times \text { FK } \\
& \text { FK = faktor konversi } 6,25
\end{aligned}
$$

Analisa total gula dilakukan dengan menggunakan refraktometer. Prinsip kerja refraktometer adalah menyerap cahaya yang terdapat pada sampel. Prosedur kerja : sampel di haluskan, kemudian diteteskan pada prisma. Refraktometer menghasilkan data total gula dalam satuan brix.

Uji organoleptik dilakukan dengan menggunakan uji hedonik dengan skala 1 (sangat tidak suka), 2 (tidak suka), 3 (agak suka), 4 (suka) dan 5 (sangat suka).

\section{HASIL DAN PEMABAHASAN}

\section{Kadar Air Selai Kelapa Muda}

Kadar air sangat mempengaruhi daya tahan selai. Kadar air yang tinggi akan mengakibatkan mudahnya bakteri dan jamur serta mikroba lainnya untuk berkembang biak, sehingga akan mempengaruhi mutu dari selai.

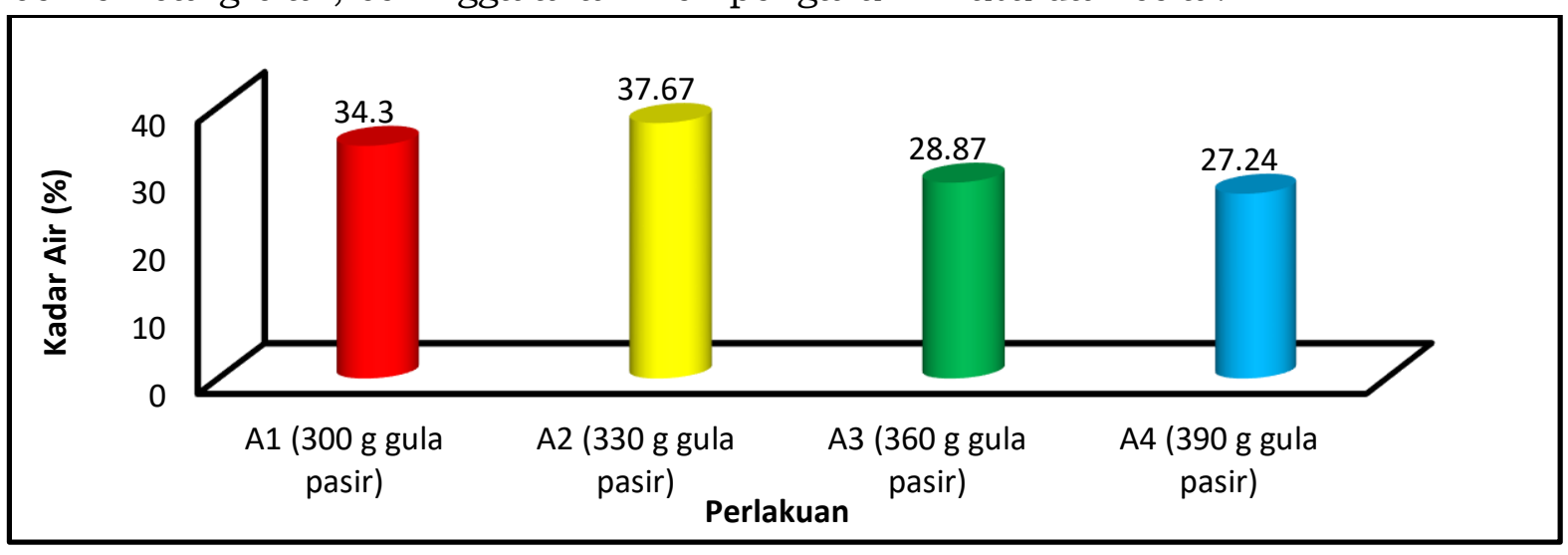

Gambar 1. Kadar Air Pada Selai Kelapa Muda

Gambar 1 menunjukkan bahwa kadar air pada perlakuan penambahan gula $300 \mathrm{~g}$ (A1) sebesar 34,3\%. Perlakuan penambahan gula 330 g (A2) kadar air sebesar 37,67\%. Perlakuan penambahan gula 360 g (A3) kadar air sebesar 28,87\%, Dan Perlakuan penambahan gula 390 g (A4) kadar air sebesar 27,24\%. Kadar air tertinggi pada selai kelapa muda sebesar $37,67 \%$ diperoleh pada perlakuan A2 (penambahan konsentrasi gula $330 \mathrm{~g}$ ). Berdasarkan hal tersebut dapat diketahui bahwa kandungan air tertinggi terdapat pada perlakuan penambahan gula $330 \mathrm{~g}$ (A2). Gula yang ditambahkan lebih sedikit jika dibandingkan dengan gula yang ditambahkan pada perlakuan A3 dan A4 sehingga air yang terserap juga sedikit, sedangkan kadar air yang terendah terdapat pada perlakuan penambahan gula 390g (A4) dengan penambahan gula 
yang paling banyak diantara perlakuan yang lain. Gula memiliki sifat menyerap air, sehingga air yang terdapat dalam selai akan diserap oleh gula sehingga kadar air dalam selai semakin menurun. Hal ini sejalan dengan pendapat Winarno (2008) yang menyatakan bahwa gula bersifat menyerap air dimana bahan yang ditambahkan gula akan mengalami tekanan osmosis yaitu tekanan molekulmolekul gula pada dinding sel (extra sel) buah sampai larutan gula masuk kedalamnya, akibatnya air yang berada dalam sel buah keluar. Salah satu faktor yang mempengaruhi kadar air disebabkan karena proses pemasakan. Semakin lama pemasakan maka kadar air semakin menurun. Hal ini sejalan dengan Wirawan dan Mushollaeni (2008) yang menyatakan terdapat hubungan antara waktu pemasakan dan kadar air, dimana naik turunnya kadar air di sebabkan oleh waktu pemasakan, sisanya di pengaruhi oleh faktor-faktor lain.

Penetapan kandungan air perlu dilakukan untuk mengetahui kondisi bahan pangan atau makanan. Menurut Sundari dan Komari (2010), Kadar air selai maksimum 35\%. Dari hasil penelitian selai kelapa muda, maka perlakuan A1, A3, A4 memenuhi standar kadar air hal ini disebabkan karena semakin banyak gula yang ditambahkan maka akan semakin menurun kadar air pada selai. Gula dapat mengisi lapisan pori-pori yang ada pada selai, ketika selai dipanaskan maka kadar air akan keluar dan menguap digantikan oleh gula. Hal ini dikemukakan oleh Mutia dan Yunus (2016), bahwa gula yang ditambahkan pada pembentukan selai berfungsi sebagai dehydrating agent, yaitu menarik molekul-molekul air yang terikat dengan molekul-molekul pektin sehingga akan mempengaruhi keseimbangan pektin dan air yang ada sehingga kekukuhan dan kekenyalan selai dapat dipertahankan.

\section{Kadar Protein Selai Kelapa Muda}

Kadar protein merupakan zat makanan yang amat penting bagi tubuh karena zat ini selain berfungsi sebagai bahan bakar dalam tubuh juga berfungsi sebagai zat pembangun dan pengatur. Protein tersusun atas sejumlah asam amino. Asam amino yang membentuk protein pada dasarnya dapat digolongkan menjadi dua yaitu asam amino esensial dan non esensial (Winarno, 2008).

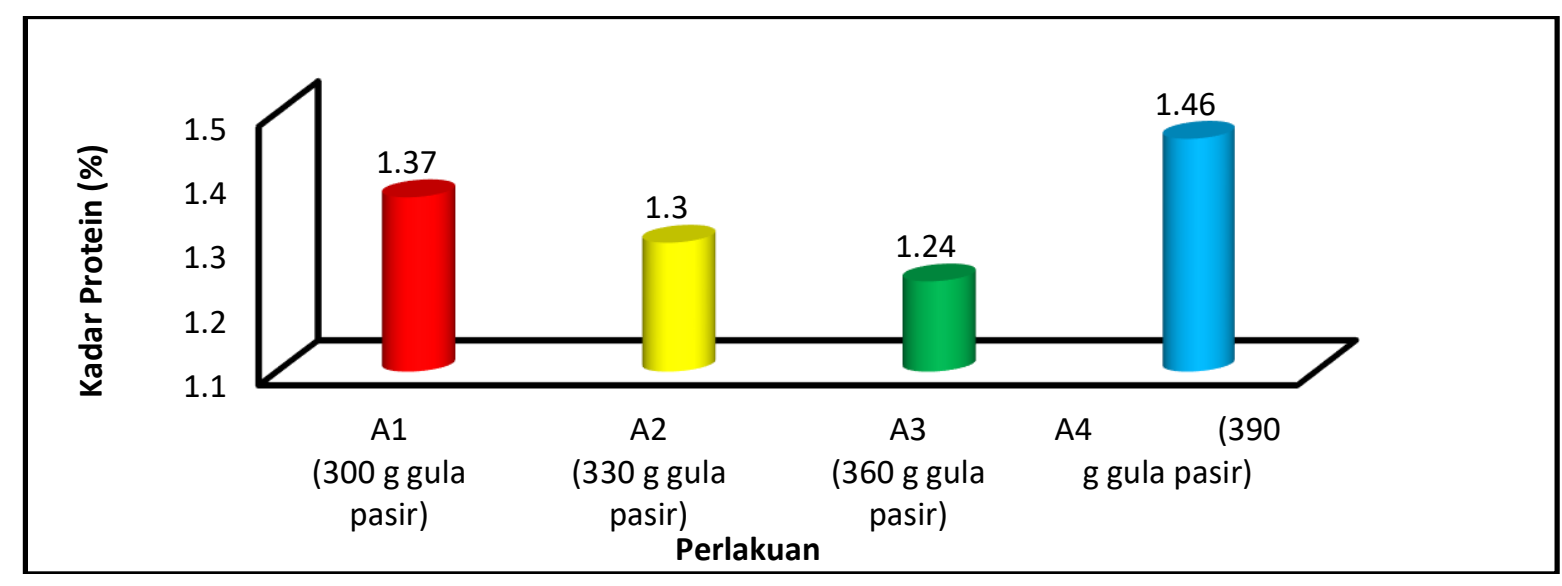

Gambar 2. Kadar Protein Pada Selai Kelapa Muda

Protein pada selai kelapa muda dengan penambahan gula 300 g (A1) sebesar 1,37\%. Penambahan gula pasir $330 \mathrm{~g}$ (A2) sebesar 1,3\%, Penambahan gula pasir $360 \mathrm{~g}$ (A3) sebesar 1,24\% dan penambahan gula $390 \mathrm{~g}$ (A4) sebesar 
$1,46 \%$. Protein yang tertinggi pada selai kelapa muda adalah perlakuan A4 (390 g gula pasir) dan yang terendah adalah perlakuan A3 (360 g) sebesar 1,24\%.

Kadar protein mengalami penurunan karena banyak faktor salah satunya dikarenakan denaturasi protein. Denaturasi protein bisa terjadi karena lama pemasakan. Protein dapat terdenaturasi melalui proses pemanasan (Irtasari, 2015). Kadar protein pada selai kelapa muda hanya berasal dari bahan alami saja yaitu air kelapa dan daging kelapa. Hal ini didukung oleh Allorerung (2008), bahwa daging buah kelapa mengandung 10 jenis asam amino esensial sehingga dapat dikategorikan sebagai bahan makanan dengan protein bermutu tinggi. Protein bermutu tinggi adalah protein yang dapat menyediakan asam amino esensial dalam perbandingan yang menyamai kebutuhan manusia.

Menurut Lobalohin, et al., (2014) Kandungan gizi daging buah kelapa perseratus gam adalah: protein 3,3 g, karbohidrat 15,23 g, vitamin C 3,3 $\mathrm{mg}$, dan energi 350 mg. Hal ini juga dikemukakan oleh Allorerung, et al (2008), bahwa.air kelapa muda mengandung air 95,5\%, protein $0,1 \%$, lemak kurang dari $0,1 \%$, karbohidrat $4,0 \%$, dan abu $0,4 \%$

\section{Kadar Gula}

Gula adalah suatu karbohidrat sederhana yang menjadi sumber energi dan komoditi perdagangan utama. Gula sebagai sukrosa diperoleh dari nira tebu, bit gula, atau aren. Gula berfungsi sebagai pemberi rasa manis, memberi energi, pada ragi/yeast sebab gula adalah makanan bagi bakteri yang ada pada yeast atau ragi tersbut, dan menampakan warna cerah yang lebih bagus pada hasil akhir pada stik (Derry et al, 2015).

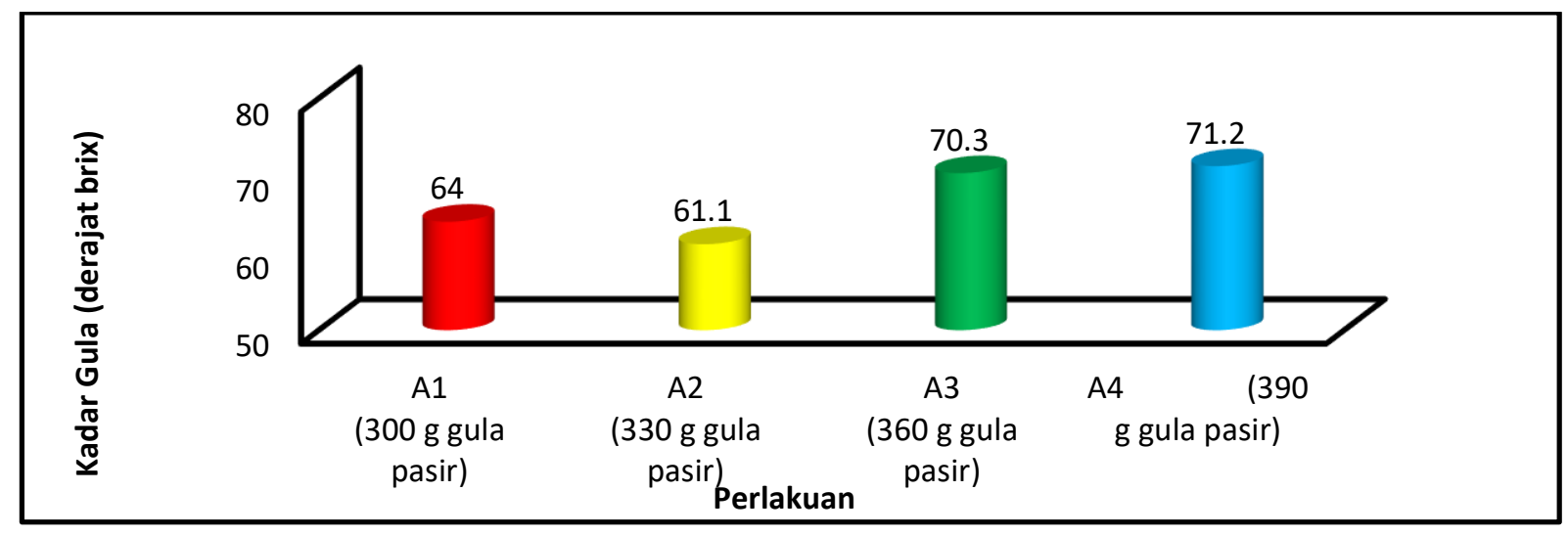

Gambar 3. Kadar Gula Pada Selai Kelapa Muda

Gambar 3 menunjukkan bahwa konsentrasi gula pada perlakuan penambahan gula $300 \mathrm{~g}$ (A1) adalah $64 \%$, pada perlakuan penambahan gula $330 \mathrm{~g}$ (A2) sebesar 61,6\%, pada perlakuan penambahan gula 360g (A3) sebesar 70,3\% dan perlakuan penambahan gula 390g (A4) sebesar 71,2. Perlakuan A1 dan A2 memenuhi standar total gula pada selai kelapa muda. Hal ini sejalan dengan Solechan dan Irma (2005) selai buah didefinisikan sebagai produk makanan semi basah, dibuat dari pengolahan bubur buah-buahan, gula dengan atau tanpa penambahan makanan yang diizinkan. Campuran ini kemudian dipekatkan sehingga akhirnya mengandung total gula minimum $65 \%$. 
Hal ini juga di kemukakan oleh Herianto, et al (2015) bahwa selai dengan campuran nangka dan belimbing memiliki perlakuan terbaik dengan kadar gula sebesar $65,97 \%$. Penambahan gula pada proses pembuatan selai menyebabkan kadar gula pada selai meningkat. Hal ini terlihat pada perlakuan A3 dan A4. Peningkatan ini terjadi seiring dengan banyaknya gula yang ditambahkam pada selai. Hal ini sesuai dengan Mutia dan Yunus (2016) bahwa kadar gula meningkat seiring dengan konsentrasi gula yang ditambahkan pada selai. Disamping itu gula pasir yang ditambahkan akan mempengaruhi terbentuknya gel, bila terlalu banyak maka akan terjadi kristalisasi pada permukaan gel, tetapi bila gula yang ditambahkan kurang, maka gel yang terbentuk terlalu lunak.

\section{Uji Organoleptik Selai Kelapa Muda}

Warna adalah salah satu atribut penting yang digunakan untuk uji organoleptik suatu produk. Warna merupakan salah satu sifat visual yang pertama kali dilihat oleh konsumen. Menurut Solechan dan Irma (2005) warna meupakan komponen penting bagi produk makanan karena warna yang menarik akan meningkatkan nilai jual produk.

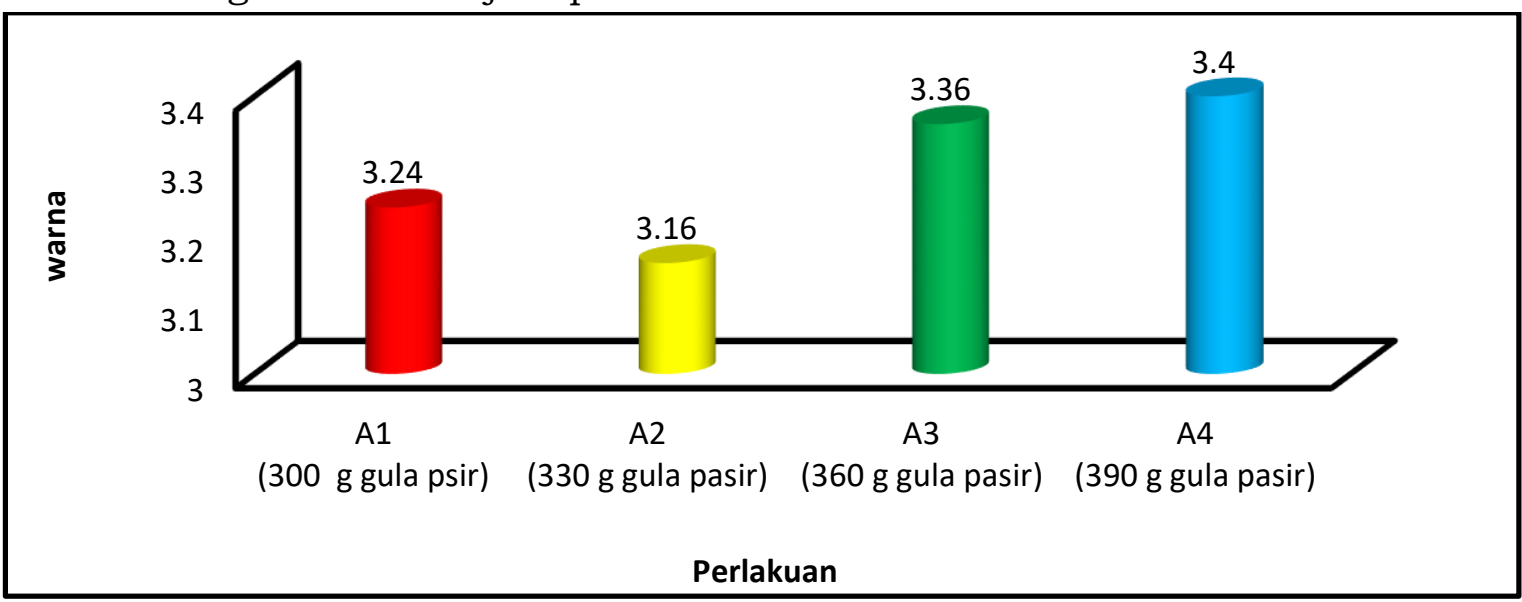

Gambar 4.Tingkat Kesukaan Panelis Terhadap Warna Selai Kelapa Muda

Gambar 4 menunjukkan bahwa perlakuan A1 (penambahan gula pasir 300g) mempunyai skor nilai 3,24. Pada perlakuan A2 (penambahan gula pasir 330g) mempunyai skor nilai 3,16. Perlakuan A3 (penambahan gula pasir 360g) mempunyai skor nilai 3,36. Dan pada perlakuan A4 (penambahan gula pasir 390g) mempunyai skor nilai 3,4.

Nilai hasil uji organoleptik tertinggi terhadap warna selai kelapa muda sebesar 3,4 diperoleh pada perlakuan A4 (penambahan gula 390g) karena warna selai kelapa muda kecoklatan. Mutia dan Yunus (2016) disebabkan karena pengaruh konsentrasi gula yang ditambahkan pada selai kelapa muda. Melihat warna yang dihasilkan, semakin banyak konsentrasi gula yang ditambahkan maka warna yang dihasilkan semakin coklat. Hal ini disebabkan gula mempunyai sifat dapat menyebabkan reaksi pencoklatan yaitu karamelisasi.

Rasa merupakan faktor yang penting dalam menentukan keputusan bagi konsumen untuk menerima atau menolak suatu makanan. Rasa sangat sulit dimengerti secara tuntas karena selera manusia sangat beragam. 


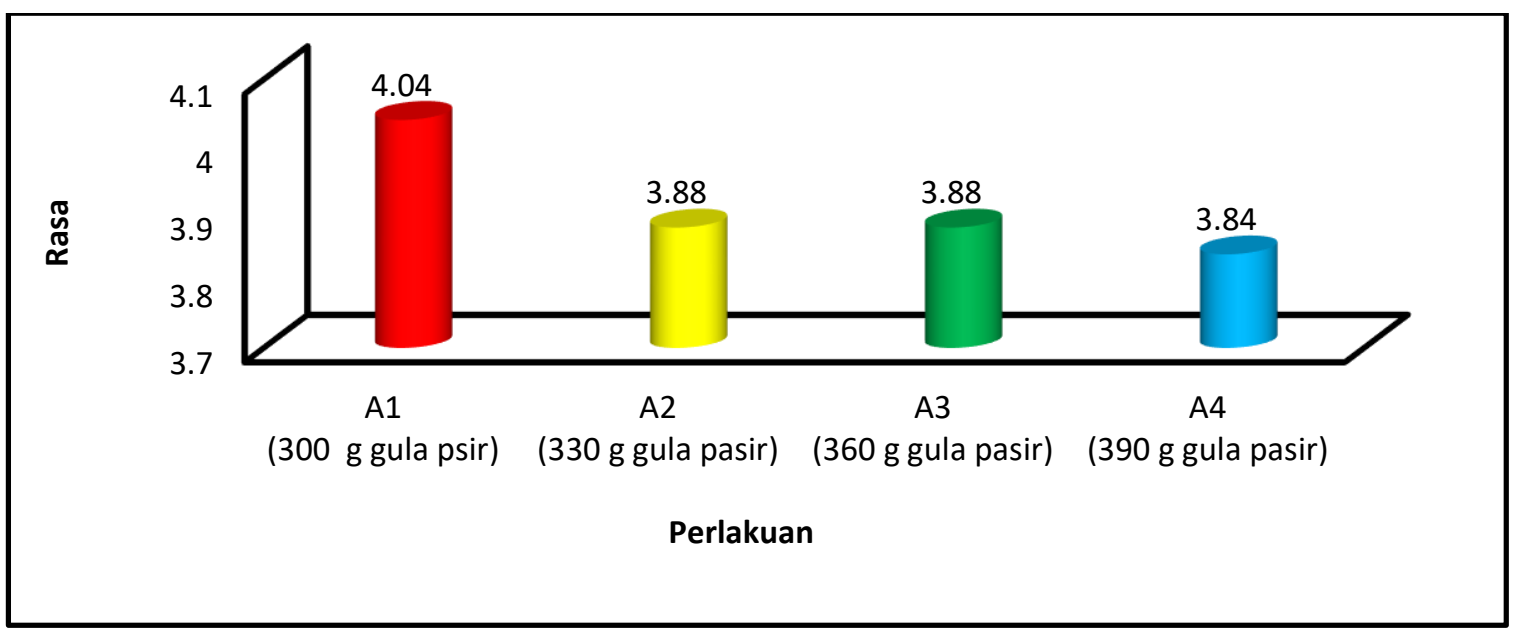

Gambar 5.Tingkat Kesukaan Panelis Terhadap Rasa Selai Kelapa Muda

Gambar 5 menunjukkan bahwa nilai uji rasa selai kelapa muda pada perlakuan penambahan gula pasir 300g (A1) mempunyai skor nilai 4,04 (Suka). Perlakuan penambahan gula pasir 330g (A2) mempunyai skor 3,88 (agak suka), Perlakuan penambahan gula pasir 360 g gula pasir (A3) mempunyai skor nilai 3,88 (agak suka). Dan yang terakhir penambahan gula pasir 390g gula pasir (A4) mempunyai skor nilai 3,84 (agak suka).

Nilai hasil uji organoleptik tertinggi terhadap rasa pada selai kelapa muda sebesar 4,04 di peroleh pada perlakuan A1 (penambahan gula 300g) karena rasa khas buah kelapa muda tidak hilang dengan rasa manis yang cukup sehingga panelis lebih menyukai perlakuan A1. Menurut Winarno (2008), rasa termasuk faktor yang penting dari suatu produk makanan disamping warna dan aroma, cita rasa ini bisa berasal dari sifat bahan yang digunakan atau pada saat proses pengolahannya ada bahan lain yang ditambahkan, sehingga rasa aslinya bisa berkurang atau bertambah tergantung pada senyawa pendukungnya, misalnya penambahan gula dapat memberikan rasa manis pada produk termasuk manisan buah kelapa itu sendiri.

Umumnya aroma yang diterima oleh hidung dan otak lebih banyak, merupakan dari berbagai campuran empat aroma utama yaitu harum, asam, tengik dan hangus. Aroma makanan banyak menentukan kelezatan dan penilaian makanan (Sundari dan Komari 2010).

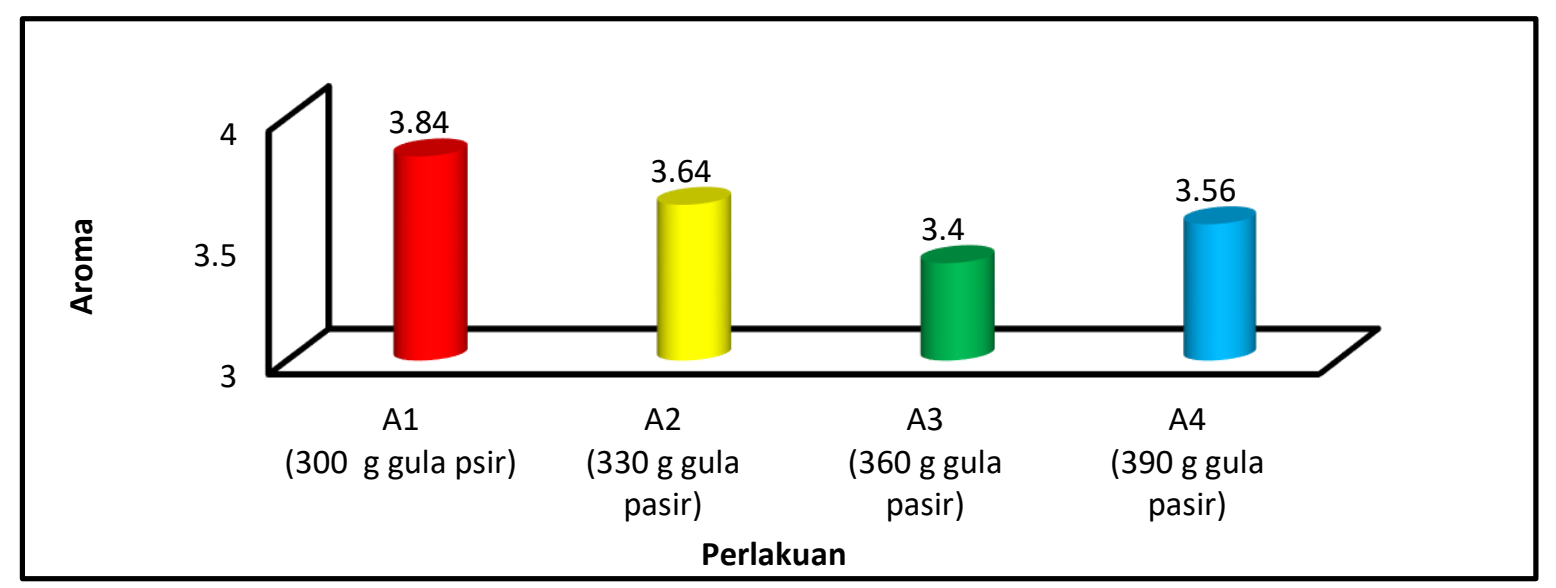

Gambar 6.Tingkat Kesukaan Panelis Terhadap Aroma Selai Kelapa Muda 
Berdasarkan Gambar 6 aroma pada perlakuan A1 dengan penambahan gula 300 g mempunyai skor nilai 3,84 (agak suka). Pada perlakuan A2 dengan penambhan gula pasir 330g mempunyai skor nilai 3,64 (agak suka). Perlakuan A3 dengan penambahan gula pasir 360g mempunyai skor nilai 3,4 (agak suka). Dan pada perlakuan A4 dengan penambahan gula pasir 390g mempunyai skor nilai 3,56 (agak suka).

Hasil uji organoleptik yang tertinggi adalah 3,84 pada perlakuan A1 (300g gula pasir) karena aroma selai kelapa muda yang dominan aroma buah kelapa muda. Winarno (2008) yang menyatakan bahwa aroma dapat di timbulkan dari aroma bahan itu sendiri dan bahan yang sengaja ditambahkan pada saat pengolahan. Hal ini juga didukung oleh Herinto, et al., (2015) komponen pembentuk aroma pada buah-buahan adalah senyawa ester yang bersifat mudah menguap atau senyawa volatile.

Tekstur suatu bahan pangan merupakan salah satu sifat fisik dari bahan pangan yang penting. Hal ini berhubungan dengan rasa pada waktu mengunyah bahan pangan tersebut. Salah satu cara penentuan teskstur suatu bahan adalah dengan memberikan beban terhadap bahan tersebut misalnya dengan pemeriksaan bekas atau tekanan jari.

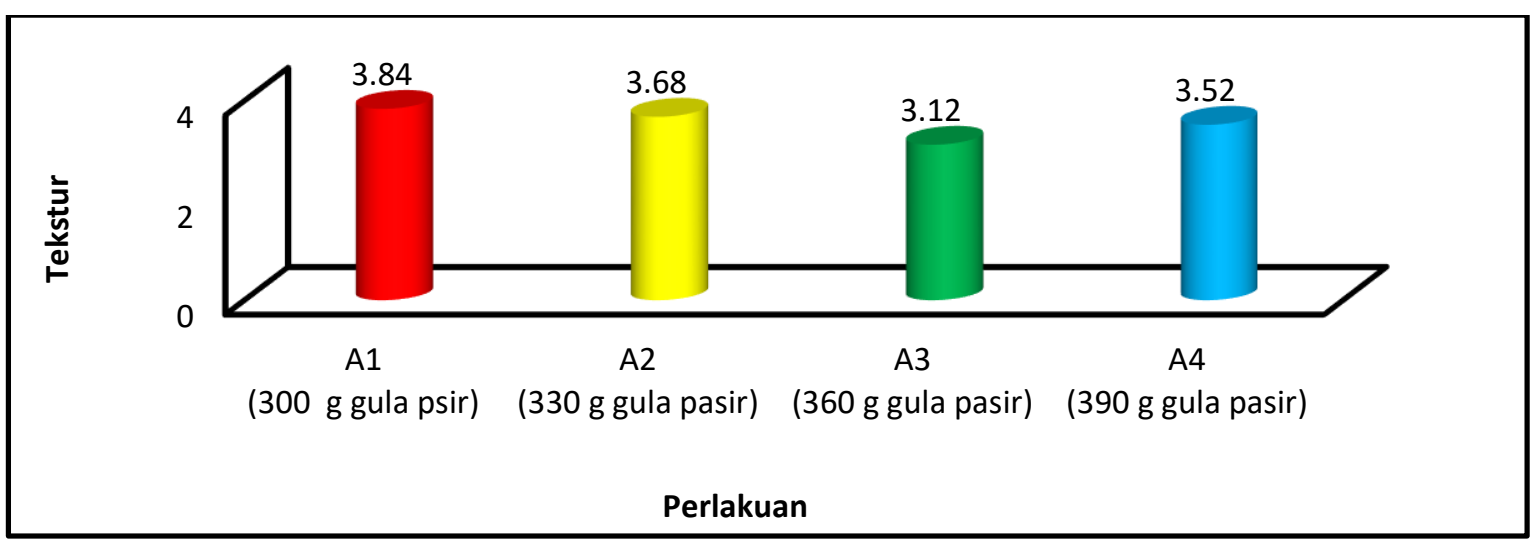

Gambar 7.Tingkat kesukaan panelis terhadap terkstur selai kelapa muda

Gambar 7 menunjukkan bahwa nilai uji tekstur selai kelapa muda pada perlakuan A1 (penambahan gula pasir 300g) mempunyai skor 3,84 (agak suka). Perlakuan A2 ( penambahan gula 330 g) mempunyai skor 3,68 (agak suka). Perlakuan A3 (penambahan gula 360g) mempunyai skor 3,12 (agak suka) Dan pada perlakuan A4 (penambahan gula 390g) mempunyai skor 3,62 (agak suka). Panelis lebih menyukai A1 disebabkan teksturnya yang sangat lembut. Menurut Herianto, et al., (2015) Tekstur selai dipengaruhi oleh pembentukan gel yang terjadi didalam selai. Kekerasan gel pada selai tergantung kepada konsentrasi gula, pektin, dan asam. Semakin banyak gula yang ditambahan, maka tekstur pada selai akan semakin kasar.

\section{KESIMPULAN}

Penambahan gula memberikan pengaruh sangat nyata terhadap kadar air, kadar protein dan kadar gula selai kelapa muda. Untuk kandungan kadar protein yang tertinggi terdapat pada perlakuan A4 berkisar 1,46\% terendah terdapat pada perlakuan A3 1,24\%. Kandungan kadar gula tertingi pada perlakuan A4 71,2\% 
dan terendah terdapat pada perlakuan A2 61,1\%., Kandungan kadar air tertinggi diperoleh pada perlakuan A2 37,67\% dan terendah terdapat pada perlakuan A4 $27,24 \%$. Uji organoleptik dari segi rasa, tekstur, dan aroma panelis lebih menyukai A1 (penambahan gula $300 \mathrm{~g}$ ), sedangkan dari segi warna panelis lebih menyukai A4 (penambahan gula $390 \mathrm{~g}$ ).

\section{DAFTAR PUSTAKA}

Allorerung, David. Zainal Mahmud dan Bambang Prastowo. 2008. Peluang Kelapa untuk Pengembangan Produk Kesehatan. Jurnal pengembangan inovasi pertanian. Vol 1 (4), 298-315.

Arindya, Allva. Rona J Nainggolan, Linda Masniary Lubis. 2016. Pengaruh Konsentrasi Karagenan terhadap Mutu Selai Kelapa Muda Lembaran Selama Penyimpanan. Teknologi ilmu pangan. Vol 4 (1), 72-77.

Barlina, R. 2004. Potensi Buah Kelapa Muda untuk Kesehatan dan Pengolahannya. Balai Penelitian Tanaman dan Palma Lain. Vol 3 (2), 4660.

Derry Candia Apriawan Irham, Jangkung Handoyo Mulyo. 2015. Analiis Produksi

Tebu dan Gula di PT. Perkebunan Nusantara vii (Persero). Fakultas Pertanian, Universitas Gadjah Mada.

Dinas Pertanian dan Ketahanan Pangan. 2016. Produksi Kelapa. Pohuwato.

Herianto,et al., 2015. Study Of The Banana Mas (Hylocereus polyrhizus) In The Preparation Of Jam. Jom faperta.Vol 2 (2), 1-12.

Irtasari. 2015. Kandungan Protein pada Kecap Air Kelapa dengan Penambahan Tepung Belalang Kayu dan Sari Buah Nanas. Naskah publikasi. Universitas Muhammadiyah Surakarta.

Ishak, E. (2012). Ilmu Pangan dan Teknologi Pangan. Makassar, Universitas Hasanuddin.

Lobalohin, Selfi. Saatje H. Noya. Jeffij V. Hasinu. 2014. Kerusakan Tanaman Kelapa (Cocos nucifera L) Akibat Serangan Hama sexava Sp. dan Orcytes rhinoceros Di Kecamatan Teluk Kelapa Putih Kabupaten Maluku Tengah. Jurnal budidaya pertanian. Vol 10 (01), 35-40.

Mutia, A.K dan Yunus, R. 2016. Pengaruh Penambahan Sukrosa pada Pembuatan Selai Langsat. Jtech. Vol 4 (2) 80-84.

Soekardi, Y. 2014. Pemanfaatan dan Pengolahan Kelapa Menjadi Berbagai Bahan Makanan dan Obat Berbagai Penyakit. Bandung, Cv Yrama Widya. Solechan dan Irma S. 2005. Mempelajari Formulasi Pembuatan Selai Lembaran Nanas dan Sirsak. Jurnal Warta IHP. Vol 22 (1), 44-53.

Sundari D, dan Komari. 2010. Formulasi Selai Pisang Raja Bulu dengan Tempe dan Daya Simpannya (Formulation The Jam Mixture Of 'Raja Bulu' Banana with Tempe and Durability). Puslitbang gizi dan makanan. Vol 33 (1), 93-101

Trisnowati, N. 2012. Pembuatan Selai Apel (Malus sylvestris Mill). Laporan. 151.

Winarno, F. G.. 2008. Kimia Pangan dan Gizi. PT. Gmedia pustaka utama. Jakarta

Wirawan dan Mushollaeni W. 2008. Optimasi Lama Blanching Pengolahan Selai Kacang Tanah Metode Regeresi Kuadrat. Buana Sains. Vol 8 (1), 73-80. 